\title{
Bringing Certainty and Order out of the Wilderness of Law
}

\section{A Common Tendency for the Clarification and Simplification of the Law}

\author{
Alessandro Martinuzzi \\ School of Law, University of Bologna, Bologna, Italy \\ Email: a.martinuzzi@unibo.it
}

Received 3 June 2014; revise 1 July 2014; accepted 25 July 2014

Copyright (C) 2014 by author and Scientific Research Publishing Inc.

This work is licensed under the Creative Commons Attribution International License (CC BY).

http://creativecommons.org/licenses/by/4.0/

cC) (i) Open Access

\begin{abstract}
The codification of the French civil law represented the first significant initiative which provided the moral and intellectual impetus for systematic reorganization and reform of the law. The growing production of laws by the legislatures, together with the courts' constant definition of the principles of law, has always constituted a massive problem in providing a service of certain and equal justice. The French model of codification was undoubtedly useful but it did not suffice, by itself, to preserve a coherent and accessible system of law. The experience of the last decades showed a proliferation of new sources of law (including multilevel systems of protection of fundamental rights) that increased the complexity of law on a more than proportional scale. In order to tackle the compelling need of certainty and order in the legal systems, the French codification approach had been developed and integrated with other simplifying and reorganizing tools. The different experiences are interesting under three profiles: a) the subjects dedicated to the function of simplifying and clarifying the law; b) the tools used to perform the function; c) the effects produced in the legal systems. The comparative analysis of the different experiences in Civil law and Common law countries reveals a major tendency to constitute independent bodies by initiative of a law experts elite of lawyers, judges and academics. Generally, these bodies adopt a scientific method in order to produce shared documents which are supposed to represent a valid reference for all the legal operators. Most of the time there is no political influence on the process, contributing to preserve the authoritativeness of the body. Notwithstanding, the documents may be addressed to the parliaments with the purpose to enact law reforms through the legislative process. Out of these cases, the documents are supposed to have mere persuasive value but it is disputed how they affect the other sources of law when they are widely adopted by courts.
\end{abstract}

\section{Keywords}

Restatement, Code, Model, Organization, Principles, Elìte, Legisprudence 


\section{Introduction}

The constant need for adaptation of the law to social exigencies, particularly concerning the service of Justice, has always fostered a proliferation of different sources of law that seems to be hardly compatible with the "rocky” Kelsenian model of lawmaking (i.e. "Stufenbautheorie") (Paulson \& Lischewski Paulson, 1998; Postema, 1987). Even if this assumption may recall the Legal Realists' theories, the point of view is intended to be more attentive to the people's right to receive the service of Justice in a system based on the rule of law, rather than to the drafting of a rigid, reliable system of sources of law legitimacy. In fact, the endeavor to provide modern constitutions with such a system did not contribute, in the long term, to the certainty of law as expected.

The right to know what is the applicable law includes the right to comprehend the law and to predict the consequences of people's actions. As far as this right is protected, the law tends to be certain. It is not a matter concerning only individuals' rights, but it involves, perhaps primarily, all the law operators (i.e. judges and lawyers). The inner idea that the law is formed more among people and before the courts, rather than in Parliaments, is considered in the Universities of the European continent as a matter belonging exclusively to the common law tradition. Notwithstanding, different globalization processes carried out multilayered systems of sources of law which definitely put in danger the pursuit of certainty in many civil law countries (quantitative profile). The expansion of international organizations' powers and the many federative processes throughout the world prove that Parliaments' legislative monopoly represents an outdated model.

The proliferation of law sources, however, is also related with the quality of the parliamentary lawmaking process. In fact, when the standards of clarity, simplification and organization of the statute law lower too much, even the interpretative power of the courts cannot help (qualitative profile). The quality standard of a statute is determined by the way it's written (formal point of view) and by the impact on the law (systematic point of view).

For these reasons, a high quantity of statute laws characterized by low quality determines a compelling need of new solutions in order to pursue a certain and equal Justice before the courts.

\section{The Experiences of Law Simplification in the Modern Age}

The codification of the French civil law under Napoleon represented the first significant initiative which provided the moral and intellectual impetus for systematic reorganization and reform of the law. The codifiers conceived the idea of simplifying and restating the vast body of earlier law, so as to make it more understandable and accessible to ordinary people. At that time, the innovative idea of a civil code inspired Jeremy Bentham and J. S. Mill in England, and their writings, in turn, promoted parliamentary revision of English law. The French model of codification was undoubtedly useful but it did not suffice, by itself, to preserve a coherent and accessible system of law. In fact, immediately after the codification, the law started to get older and integrated by new statutes while the judges were supposed to apply the law just for single cases; under the French approach, indeed, no one but the parliament could have interpreted the law.

During the $19^{\text {th }}$ Century the European civil law countries adopted this solution for restating and reorganizing their legal systems because it was considered the best way to guarantee certainty and order in a modern state. The success of the French code led to a great era of codification and statute law revision (i.e. the repeal of obsolete or redundant statutes), but it was not supported by the unanimity of the European doctrine. In fact, in 1814 Friedrich Karl von Savigny wrote one of his masterpieces, Vom Beruf unserer Zeit für Gesetzgebung und Rechtswissenschaft (On the Vocation of Our Age for Legislation and Jurisprudence), firmly criticizing the codification process on the base it was too influenced by legal positivism under which law-making had nothing to do with jurisprudence (Berkowitz, 2005). Von Savigny withstanded the idea, common to $18^{\text {th }}$ Century jurists and Bentham, that law can be arbitrarily imposed on a country irrespective of its state of civilization and history. He called, on the contrary, for a constant effort involving all the jurists with the purpose to reorganize the legal system. However, Von Savigny did not oppose to the introduction of new laws or of new system of laws and, eventually, he helped for the introduction of the new Prussian codes. Later, in the $20^{\text {th }}$ Century, the French codification approach combined with the Kelsenian model of "Stufenbau", legitimating the rule of law under the authority of the constitution. So far, the sources of law were supposed to be typical, limited, legitimate and well regulated in a close coherent and complete legal system. In England the process of statute law revision began in 1868 (Etherton, 2007) when Lord Chancellor Cairns appointed the Statute Law Committee with the task of producing a revised edition of the statutes and of supervising progress on statute law revision and consolidation. 
Then, in 1934, Lord Sankey created the Law Revision Committee with the purpose of general reform of the law rather than merely repeal and consolidation of existing statutes (Etherton, 2007). It can be said the English approach in addressing the need of reorganization and restating the law was centered on the creation of a ministerial committee which gathered judges, barristers, solicitors and legal academics because of their fundamental function in applying the law.

\section{The American First Approach to the Simplification of the Law}

On the other side of the Atlantic, while a New York attorney named David Dudley Field was strongly advocating a codification of the state procedural rules, the United States Congress undertook the first official codification (i.e. Revised Statutes approved on June 22, 1874) for the laws in effect as of December 1, 1873. The Revised Statutes were enacted as positive law, but subsequent enactments were not incorporated into the official code, so that over time researchers had to delve through many volumes of the Statutes at Large again. From 1897 to 1907 a commission was engaged in an effort to codify the great mass of accumulating legislation. Although much money was invested in the project, the work of the commission was never carried to completion (Lee \& Beaman, 1926). During the 1920s, the essential need to manage the growing wilderness of statutes brought some members of Congress to revive the codification project and, as a result, in 1926 the United States Code was approved. However, the Code enacted no new law (not substantially), repealed no prior law and, in cases of inconsistency, the statutes were to prevail (Lynch, 1997). In other words, this form of massive consolidation confirmed all the limits of the codification approach.

In the meantime, the Harvard Law Review published in 1921 Justice Cardozo's article A Ministry of Justice where the eminent American author stressed the need for better communication between courts and legislatures in an effort to promote better lawmaking (Cardozo, 1921). Justice Benjamin Cardozo's concept of a "Ministry of Justice" has captured the imagination of judges, academicians, and practicing attorneys for more than eightyfive years now. Indeed, what Cordozo intended with that concept is radically different from what it would signify for a European scholar. In Italy, for instance, the so called "Ministro di Giustizia” (i.e. Ministry of Justice translation) represents the political apex of the judicial administration (i.e. the head of the Department of Justice). The notion Cardozo intended with that concept recalls, under a different point of view, the idea of a "Department of Public Justice” theorized by Lord Brougham and, later, by Jeremy Bentham (Kramer, 1991). The common idea is that the rise of statutory law had taken away some of the tools judges had traditionally used to effectuate just results when applying the law to the facts of individual cases (Calabresi, 1983). As a consequence, Cardozo assumed, when modern judges encounter law they believe to be wrong, they are inclined to denounce the law but not to change it (Cardozo, 1921). In other words, Cardozo criticized the idea of judges as "bouche de la lois" because they cannot make justice in an unjust system. They should communicate with the legislature because they are supposed to give a prescriptive meaning to statutes' words. The problem is made worse by legislatures' common practice of drafting statutes in a piecemeal fashion rather than methodically addressing an entire area of law at once. This legislative practice, Justice Cardozo indicated, has resulted in poorly drafted statutes that make it difficult for judges to balance the needs of consistency and predictability with the natural and appropriate desire to reach the right result in each case as a matter of justice (Cardozo, 1921). This last objection, however, was supposed to be addressed partially with the ongoing codification process.

\section{An Innovative Model: Justice Cardozo's Ministry of Justice}

In responding to these problems, Justice Cardozo called for the creation of a new institution referring to it as Ministry of Justice. Professor K. D. Adams properly observed (Adams, 2007a) that Cardozo's proposal was ambitious in that it purported to address not only ambiguous law, but also unjust and antiquated law; at the same time, the proposal was modest in that it envisioned an entity that would "watch", "observe", "report", "classify", and "criticize" (Cardozo, 1921), but apparently did not intend that this entity would itself have the power to change the law (Cardozo, 1921). The major purpose of the Ministry of Justice, as Justice Cardozo envisioned it, was to prepare statutes setting forth general principles of law to assist judges on making better decisions (Cardozo, 1921). He described this project as a modest form of legislation, less exhaustive in coverage than a code but encompassing many areas of law (Cardozo, 1921). In performing its work, the Ministry of Justice that Cardozo envisioned was to be independent of both the Judiciary and the legislature, thereby enjoying the benefit of a neutral, detached perspective and the luxury of sufficient time to accomplish its task methodically (Cardozo, 
1921), rather than in response to external pressure. Hence, Cardozo's Ministry of Justice seems to be distant from the English model of ministerial committee which is subject to the authority of the Lord Chancellor. Another matter of difference between the two models resides in the nature the Ministry of Justice was supposed to have. In fact, Justice Cardozo did not exclude the principle of horizontal subsidiarity delivering the idea that, unless some private entity were to prove itself equal to the task, the Ministry of Justice should be a governmental agency staffed by full-time public employees (Cardozo, 1921).

At least one scholar (Vetri, 1998) recognized another peculiarity of the Ministry of Justice in that its area of interest would have been limited to matters of private law. In fact, laying the foundation for his proposal, Cardozo mentioned the failure of the European continental courts to address commercial needs, and their resultant loss of legitimacy in mercantile disputes (Cardozo, 1921). As a consequence, the merchants began to resolve their disputes outside the court system (Cardozo, 1921). The actuality of Justice Cardozo's assertion is shown by the astonishing expansion of ADRs in the area of commercial law such as, for instance, the many international arbitration models adopted worldwide and the permanent courts of arbitration (Indlekofer, 2013; van den Berg, 2013). Justice Cardozo's reference to this phenomenon could be read to indicate that it was a major impetus for his proposal, and may also suggest that the Ministry was to be limited to commercial disputes. Further support for this peculiarity of the Ministry of Justice can be found in Cardozo's statement that "the great fields of private law" are in need of a "caretaker" (Cardozo, 1921). Moreover, it's not a matter of little importance that since 1919 Congress had been working on a massive reorganization of the general and permanent laws of the US through a codification process (i.e. U.S.C.) (McKinney, 2006). The Code was not supposed to include private and local matters, nor annual appropriations. Justice Cardozo was aware of this process and he could have interpreted the House Committee on the Revision of Laws (i.e. the entity where the codification initiative started) as the "public law caretaker". As a matter of fact, no project for reorganizing and restating the entire area of private law was ongoing at that time. For these reasons, the assumption of Professor Vetri may be well founded.

Under the different point of view of the subjects involved in the institution activity, the Cardozo's model and the English model look like to be closer. Although Justice Cardozo stated that determining the precise composition of the proposed Ministry was not a major goal of his proposal (Cardozo, 1921), he emphasized that both scholarly, philosophical perspective and practical viewpoints were to be represented (Cardozo, 1921). The mix of persons Justice Cardozo had in mind included practitioners, judges and academicians because of the function they play in the Justice service. For this reasons, it seems that both English and Cardozo's models revived von Savigny's theory on the base of a common and constant effort in reorganizing and restating the law by the law operators community.

\section{The American Experience as Actualization of the Savigny's Theory}

Savigny considered law to be an emanation of a people's spiritual and historical experience. It "is first developed by custom and popular acceptance, next by judicial decisions-everywhere, therefore, by internal silently operating powers, not by the arbitrary will of the law-giver". The essential prerequisite was a deep and farreaching appreciation of the genius of a particular Volk; therefore, the prescriptive content of the law must accord with the Volksgeist (i.e. people's spirit).

Although law initially manifests through custom, as social activity and rules grow more complex, specialist body of lawyers emerges. The lawyers who formulate law for an advanced culture serve as the representatives of the legal Volksgeist. A similar idea about lawyers was contemplated by Alexis de Tocqueville with specific regard to the American system. Quoting the French author:

"The government of democracy is favorable to the political power of lawyers; for when the wealthy, the noble, and the prince are excluded from the government, the lawyers takes possession of it, in their own right, as it were, since they are the only men of information and sagacity, beyond the sphere of the people, who can be the object of the popular choice."

So far, lawyers together with judges tend to constitute an influential elìte of law experts that, like a clergy, are exclusively in charge with the task of allowing access to Justice. As a consequence, the complexity of law is supposed to vary on a proportional scale with the social importance of the "law clergy".

Combining historical knowledge of the law with a conceptual, systematic understanding of how the rules interrelate with one another and with the whole, jurists separate what still has validity from that which is lifeless "and only belongs to history", arriving thereby at a "living customary law" (von Savigny, 1814). This concept is 
progressively more often adopted by civil law tradition courts in order to justify the utility of jurisprudence where the judicial precedent is supposed not to have a binding efficacy. For instance, the Italian Constitutional Court did use the concept of "living law" in 677 decisions while the times the Italian Supreme Court of Cassation mentioned the concept are uncountable. Notwithstanding, the European doctrine still doesn't show to rely extensively on the concept of "living customary law" because it tends to put in danger the codified Kelsenian model of European continental law.

\section{The Ground for the Development of New Theories}

Justice Cardozo's Ministry of Justice and the English Law Revision Committee may be considered post-codification models for simplifying and reorganizing the law in order to make it more certain and, as a consequence, in order to make the Justice service more accessible to ordinary people. These models take place between, on one side, the codification approach as the best solution to have an instant "photograph" of the applicable law (i.e. code) and, on the other side, the absolute power of courts to decide what is the applicable law case by case (i.e. adjudication as judge-made-law). The area between the two poles is progressively getting wider, encompassing many other new models drafted to restate and reorganize the living law (Cardozo, 1924). The study of this wide grey area has been named by some scholars as "legisprudence". The leitmotif of this theory is the reversal of the legitimation chain in modern democracies between citizens and legislators (Perju, 2009). Professor Wintgens, indeed, argues that the social contract theorists Hobbes and Rousseau fail the promise of modernity by reviving premodern attempts to portray law as a representation of the natural order, rather than as an artifact of human will (Wintgens, 2007). In Wintgens's view, one effect of this social contract theory is to reinforce the "thereness" of a legal system which remains outside of the reach of self-governing citizens whose freedom it constrains. Under this view, the concept of "living law" tends to be wider because it is based on a rational justification of the law which involves social and historical considerations. Another important effect of this theory is a blurring of the distinction between construction and representation. In fact, Wintgens does not argue that judicial review undermines the dignity of rational legislation. To the contrary, he lists judicial review, alongside referenda or elections, as a practice that reverses the legitimation chain in modern democracies (Wintgens, 2007). It is undisputed that when courts apply the method of proportionality to demand reasons in order to review the validity of legislation, they tend to force the legislature in the direction of greater rationality. Proportionality is, indeed, a successful modern method that courts use in structuring the inquiry into the validity of legislations under that legal system's constitution. However, while judges in different legal systems differ in how they apply the proportionality test, they tend to defer to the legislator in the preliminary inquiry about the purpose of the law, and in the secondary inquiry involving the suitability of the legislation under review as the chosen means for accomplishing the purpose. Judicial deference represents a direct consequence of the traditional theory of separated powers. However, as Professor Perju stated (Perju, 2009), it is impossible to replace structural deference with substantive engagement without a theory that provides the terms of engagement between the courts and the legislature at the early steps of the proportionality analysis. The purpose of legisprudence is to provide that theory. Wintgens and Perju agree on the need to articulate principles of legislation that will recast how courts and legislators interact, as the core of the theory. Have these principles of legislation anything in common with the general principles of law Justice Cardozo had in mind as major task of his Ministry of Justice? Whether the two concepts overlap each other is unclear, but the common ground is undoubtedly a need for "better communication between courts and legislatures” (Cardozo, 1921). The relation between legisprudence theory and Cardozo's intuition is still questionable. Is legisprudence related with the research for the mediating philosophy Justice Cardozo referred to in The Growth of the Law (Cardozo, 1924)?

After Justice Cardozo's article, many different theories and models have been developed in order to address this need, contributing to the widening of the legisprudence theory.

\section{The American Legal Institute as an Ideal Model}

Professor K. D. Adams (Adams, 2007a) recognized the American Law Institute as the best concretization of Justice Cardozo's model. As a matter of fact, the Institute was founded in 1923 (two years later Cardozo's article) after a blue-ribbon committee recommended the establishment of an independent organization to be composed of outstanding practicing lawyers, judges and academicians with the general task of making the law simpler and more certain. According to the "Committee on the Establishment of a Permanent Organization for the Improve- 
ment of the Law” part of the law's uncertainty stemmed from the lack of agreement on fundamental principles of the common law system, while the law's complexity was attributed to the numerous variations within different jurisdictions (White, 1997). Hence, the core tasks of the ALI were supposed to be, on one side, the setting forth of general principles of law and, on the other side, the drafting of projects that would pursue uniformity among jurisdictions. The first and most successful ALI's project was the Restatement. Restatements are essentially codifications of case law, common law judge-made doctrines that develop gradually over time because of the principle of stare decisis (Adams, 2007b). Although they have no binding efficacy in and of themselves, they are highly persuasive because they are meant to reflect the consensus of the legal community as to what the law is (or should be). To this extent, the Restatements are supposed to put the Volksgeist in black letters. Thus over time the judicial citation of the Restatements as a source of the better view of the law multiplied with some rapidity. Interestingly, the first endeavor about Principles turned out to be a major outgrowth of the Restatement work. In fact, when the ALI started addressing corporate governance, it soon became evident that restating the law was only a fraction of what should have been done and that prudent arrangements for such a matter would have also required substantive changes in the law beyond what courts would have been able to achieve by themselves. As explicitly stated by the ALI itself, Principles may be addressed to courts, legislatures or governmental agencies and they assume the stance of expressing the law as it should be, which may or may not reflect the law as it is. In this sense, the ALI's Principles may be a key concept to improve the communication between courts and legislatures under Justice Cardozo's point of view. For the same reasons, the ALI's Principles are fit to be the pivot of any legisprudence theory.

\section{The Adams' Taxonomy in a Comparative Context}

\subsection{The Need to Face the "Statutorification"}

Regardless of her opinion about the ALI, Professor Adams proposed a taxonomy of the other different models she recognized as derived from Justice Cardozo's Ministry of Justice (Adams, 2007a). The Adams' taxonomy was based on the motivation the model was designed for: a) the need to face the rise of statutory law; b) the need to balance the increased pressure on the courts; c) the need to solve the problem of bad or obsolete law.

The first category includes a model introduced by Judge Henry Friendly with the article The Gap in Lawmaking-Judges Who Can't and Legislators Who Won't (Friendly, 1963). Friendly's program was intended to address the problem of incomplete lawmaking and, perhaps due to his understanding that such an ambitious agenda could succeed only if particular attention were given to the issue of legitimacy, it was to be overseen by the legislature, rather than affiliated to the judiciary or independent of both (Friendly, 1963). The agency Friendly proposed was to include four legislators, to be chaired by a retired federal judge, and to include four to six additional scholars, retired judges, and senior attorneys. Regardless of the limited task of this model, it resembles the English Law Commission as derived from the original ministerial committee model. The actual Commission has been instituted in 1965 through a Parliament Act. It fulfills its technical function with a sort of independence, but the legislature's affiliation derived from: a) five years appointment of the Commissioners by the Lord Chancellor; b) mandatory consent of the Lord Chancellor for any program of work; c) determination of the Commissioners' remuneration by the Lord Chancellor, with the consent of the Minister of Treasury. The primary duty of the British Law Commission is definitely wider than the one Judge Friendly had in mind for his model, but the legislature's affiliation constitutes a common character. Indeed, Judge friendly indicated that the legislative nature of the solution would be an important factor in ensuring its credibility under two profiles: a) it entails popular accountability; b) it doesn't interfere with the principle of separated powers. Like Judge Friendly's model, the Law Commission's work does not constitute a source of law without Parliament approval. However, the undisputed success of the Commission is proved by statistics: more than two thousands statutes have been totally repealed and many other thousands just partially; more than two thirds of the Commission reform projects have been approved and implemented by the English Parliament. A much stronger legislature's affiliation characterizes also the Italian Committee on Legislation. This permanent Committee has been introduced with the parliamentary regulation reforms of 1997 and it has the purpose of rationalizing the legislative process in order to improve the quality of statutes (Trantino, 2002). However, under the Italian House of Representatives rules, the Committee may carry out its task just by issuing technical and analytic statements about the quality of statutes' projects with regard to their homogeneity, clarity and efficacy. In other words, the Committee is supposed to provide the legislative commissions of the Parliament with some technical parameters in order to im- 
prove the formulation and organization of statutes which are not yet approved. Even if the Committee constitutes an internal organization of the Italian Parliament, a sort of independence comes from its joint composition by majorities and minorities and from a system of rotating presidency. However, the impact on legislation of the Committee's work is quite weak (Zaccaria, 2011). In fact Committee's statements are not mandatory (except in case of delegated legislation) (Bientinesi, 2002) and the legislative commissions don't always motivate why they decide not to conform to the Committee's statements. Furthermore, statistics about the Committee's work prove its little relevance: less than $30 \%$ of the Committee's statements have been implemented in the legislative process (Trantino, 2002). To this extent, it's quite clear that the Committee's statements by themselves cannot have any practical value for courts or lawyers.

Although all of these models are characterized for a certain explicit affiliation to legislature, a sub-distinction may be appropriate in this context. Judge Friendly's model as long as the English Law Commission are supposed to fulfill their task working on existing law, while the Italian Committee on Legislation is supposed to deal with statutes which are not yet entered into force. This difference must be taken into consideration in order to appreciate the eventual utility of the models. Under this profile, the US Office of the Law Revision Counsel constitutes an intermediate model because, like the English Commission, it deals with enacted statutes and it does not depend from a political initiative while, like the Italian Committee, it submits recommendations to the Committee on the Judiciary and it constitutes a nonpartisan office within the House of Representatives under the authority of the Speaker of the House.

The need to face the rise of statutory law motivated also Justice Ruth Bader Ginsburg's model in response to the Hruska Commission's call for a National Court of Appeals (Commission on Revision of the Federal Court Appellate System, 1975). This report received renewed attention following Justice White's 1982 address before the American Bar Association, in which he spoke of the Supreme Court's increased caseload. Indeed, the general assumption was that greater uncertainty encourages parties to believe they always have a chance of victory on appeal, if only the right panel of judges is selected for the case. Justice Ginsburg, however, rejected the idea of a National Court of Appeals and she proposed the constitution of a legislative statutory revision committee with the purpose to determine legislative intent so to pursue uniformity among jurisdictions. This model of committee was intended to address Congressional commands that are un, imprecise or gap-ridden (Ginsburg \& Huber, 1986; see also Ginsburg, 1987). To this extent Justice Ginsburg's model seems to be closer to the Italian Committee abovementioned.

Another model based on the need to face the so called "statutorification" (Calabresi, 2012) is the one proposed by the Chief Justice Roger Traynor. Under Traynor's perspective, the proliferation of statutes has provided judges with rich sources of reasoning by analogy (Traynor, 1968) but no guidance for uniformity. For this reason, Traynor called for the constitution of a "teamwork" including academicians, and other commentators and researchers, "watchbirds", and judges to ensure "better use in the judicial process of the good laws that often emerge amid the variegated products of the legislative process." (Traynor, 1968) With regard to the purpose and to the composition, Justice Traynor's model is not far from the Italian Observatories on Justice established within the Italian Courts of Appeals. The Observatories are permanent organizations constituted spontaneously by the initiative of lawyers, and judges, with the eventual involvement of academicians. Their activity is intended to recognize and restate common rules among the many different settled practices or consolidated orientations adopted by courts throughout the Italian jurisdictions (Berti Arnoaldi Veli, 2011). The Observatories' purpose is to set forth "protocols" of common rules which can help lawyers and judges improving the Justice service and, eventually, contributing to the uniformity of jurisdictions. In fact, when a particular protocol turns out to be successful, it may be adopted by other Tribunals or Courts and so followed in the cases therein. Even if the protocols are primarily directed to judges and lawyers, some of them have been implemented by the National Legislature in contexts of procedural law reforms. Hence, Observatories' protocols are of great utility for both courts and legislature and, to this extent, they tend to improve the communication between judges and Parliament in the sense Justice Cardozo intended. The problem relating the compatibility of the protocols as a source of law with the principle of separated powers in the context of a civil law tradition system has been addressed by the Italian majoritarian doctrine on the base of a mere persuasive authority (Caponi, 2011). However, it seems to be an unsatisfactory solution at least under two profiles: a) it doesn't answer the question about the relation between protocols, jurisprudence, and the living customary law; b) it is not compatible with the responsibility of judges who disobey to a decree adopted by the Tribunal they belong or directly by the Superior Council of the Judiciary. Moreover, the compatibility of the protocols with statute law has been addressed by the Italian Con- 
stitutional Court in the case relating to the constitutionality of art. 139, leg. decr. September 7, 2005, n. 209 (i.e. Private Insurance Code). In that case the Constitutional Justices qualified the protocols as "jurisprudential source of law" and, therefore, they assumed that a protocolar rule may have efficacy to the extent it is officially adopted and applied by the specific jurisdiction. However, the Court did not solve explicitly the conflict between statute law and protocols, because it decided the case on very different bases related to formal aspects.

The problem about the source of binding authority has been addressed quite differently in a similar context by France. In fact, since the '80s the heads of the France jurisdictions (Canella, 2011) started stipulating collective covenants with the Bâtonniers (i.e. Presidents) of the local Bar Associations in order to regulate the judicial procedure (Magendie, 2004). At the beginning this covenants were spontaneously adopted to pursue uniformity among jurisdictions in a system that allows the parties of a single case to decide, together with the judge, the progression order of the case (i.e. something similar to the English case management). This model was, then, taken into consideration by the commission constituted by the government with the purpose to modernize the civil procedural law and to face the problem of the unreasonable delay of the Justice service (Magendie, 2004). The problem of the courts' dockets overload and the consequent delay of the Justice service seems to be not far from Justice Ginsburg's main concern as abovementioned (Ginsburg \& Huber, 1986; see also Ginsburg, 1987). The commission eventually proposed to develop the collective covenant model (Tudela, 2006) on the base of the success of this autonomous source of law. The collective covenants are effectively contracts (actually named contrat de procédure at art. 764 c.p.c.) intended to be applied by all the subjects operating in a particular jurisdiction. However, it's not of little importance that, generally speaking, a contract provision is not fit to bind who didn't join the stipulation of it. Indeed, the binding authority of contracts is different from the one statutes are supposed to have. Notwithstanding, under the collective covenant model, the contractors represent a particular community of judges and lawyers (i.e. a local jurisdiction). These peculiar contractors, in fact, have the power to set rules and to adopt disciplinary sanctions towards the subjects of the community. As a consequence, the contract may have a legitimate, extended and indirect efficacy towards the community members. If this is a weakened source of law provided with more than a mere persuasive authority is still disputed. However, a contract theory is hardly compatible with the Stufenbau model of heterogeneous sources of law. In France, though, the Constitution doesn't include the civil judicial procedure among the subject matters that must be regulated by national statutes. For this reason, the French collective covenants may find a place among the sources of law more easily that it would be in Italy (Cadiet, 2006).

However, the French model of collective covenant suggests a sort of legitimation which is totally different from the one Justice Traynor envisioned. In fact, Traynor's “teamwork” would ultimately rely on the legislature which is still qualified as "dominant lawmaker".

\subsection{The Concern about the Increased Pressure on the Courts}

Like the French model of collective covenant and the Italian Observatories on Justice, another model put greater attention to matters of procedure as a key factor in order to face the problem of overburdened courts. In fact, Professor Larry Kramer proposed the creation of an agency that would help Congress to make better-informed decisions about federal-court jurisdiction when enacting new laws, carefully considering the impact of new causes of action on the federal-court system. The Kramer's agency would endeavor to improve the communication and coordination between the judiciary and the legislature, focusing more on matters of procedure and planning than the substantive review of the law. Apparently, therefore, the main concern is not the so called "legislative bulimia” (Berti Arnoaldi Veli, 2011), but the increased pressures on courts. For this reason, Professor Adams included the Kramer's model in the second category of her taxonomy (Adams, 2007).

The same category, not surprisingly, includes a model affiliated to the judiciary. In fact, Adams reports, Judge Wilfred Feinberg suggested (Feinberg, 1976) that the Judicial Conference of the United States designate a small number of academicians to work part-time, gathering information regarding relatively uncontroversial circuit splits that likely could be resolved without significant difficulty. Like the Italian Observatories, Feinberg's teamwork of academicians would focus on uncontroversial matters in order to be more effective. On the contrary, Justice John Paul Stevens believed that the problem of overburdened courts requires first to clarify ambiguous legislation in order to prevent the rise of disputes and controversies. For this purpose, Stevens recommended a Congressional standing committee (i.e. legislature affiliated) that would propose corrective legislation whenever needed (Stevens, 1982). To this extent, the Stevens' model is comparable with the Italian Committee on Legis- 
lation or with the English Law Commission. In Stevens' opinion, the doctrine of judicial restraint also raises the question whether the conflict resolution task need always be performed by judges. If the conflict is on a question of constitutional law, it must be resolved by the Supreme Court. But if the conflict, Stevens stated, is over the meaning of an ambiguous statutory provision, it may be both more efficient and more appropriate to allow Congress to make the necessary choice between the alternative interpretations of the legislative intent (Stevens, 1982). Interestingly, the Stevens' reasoning reminds the origins of the French Cour de Cassation. In fact, at the very beginning, the Cour could not be qualified as a traditional Supreme Court because it didn't belong to the Judiciary but, rather, to the legislature. The original purpose of the Cour was to prevent the distortion of the legislative intent through judicial interpretation (Punzi, 2010; Calamandrei, 1976). Under this view, only the Parliament has the authority to say what is the law. Apparently, Stevens felt more comfortable relying on the traditional principle of separated powers with regard to the sources of law.

The same point of view should have persuaded also Chief Judge James Oakes and Professor Eric Gouvin to the extent they both propose to tackle the pressure on the courts from the Congressional chambers. Oakes recommended the introduction of a "judicial impact checklist" for each new piece of legislation (Oakes, 1989; Flores, 1995). The idea of an impact analysis found a significant realization with the President Reagan's Executive Order 12291 by which all the governmental agencies were obliged to submit such a document to the Office of Information and Regulatory Affairs (Radaelli, 2001). The model of a mandatory impact analysis on regulation has had many different applications in the OECD countries. Although its undisputed success, this model is merely intended to provide legislatures with better information on the prospective effects a bill may have. With regard to the Oakes' proposal, the judicial impact was supposed to be a parameter for the legislator about the judges' reaction to a bill's introduction. Under a comparative point of view, this model resembles the Italian AIR (Analisi di Impatto sulla Regolazione-Analysis of the Impact on Regulation) or the Dutch LEDA (Legislative Design and Advisory system).

Professor Gouvin, instead, envisioned the Office of the Law Revision Counsel as a perfect legislative committee which can fulfill the task Justice Cardozo had in mind for his Ministry of Justice (Gouvin, 1994). However, as Gouvin himself admits, political realities may prevent the Office from effectuating change, even if it were granted the power to do so. The same limitation attributed to the Gouvin's model characterizes also the Italian Committee on Legislation and, to some extent, the English Law Commission.

\subsection{The Problem of Bad and Obsolete Laws}

The idea of Congress as dominant lawmaker is at the base of another model which, for the Adams' taxonomy, was motivated by the problem of bad or obsolete law. Professor John Copeland Nagle advocated for a program called Congressional Corrections Day as a wholly legislative solution to the problem of erroneous or obsolete laws (Copeland Nagle, 1996). In Nagle’s opinion theories that emphasize the statutory text and legislative intent are more likely to rely on Congress to correct statutory mistakes. Differently, theories that consider other factors, such as current societal norms and congressional preferences, are more likely to give courts and agencies a role in correcting mistakes. These more dynamic, less originalist theories, Nagle believed, justify their reliance on courts and agencies to correct statutory mistakes in part on the inability and unwillingness of Congress to correct its own mistakes and the interpretative mistakes made by courts and agencies. The mechanism Professor Nagle had in mind was a Congressional Corrections Calendar of up to 20 or 30 "Corrections Acts" per month, addressing legislation "that [has] an unintended consequence or $\cdots$ [is] particularly destructive in implementation." (Copeland Nagle, 1996). The idea of a Congressional mechanism to correct the interpretative mistakes made by courts recalls the original purpose of the 1790 Cour de Cassation as abovementioned (Punzi, 2010; Calamandrei, 1976).

The last model Professor Adams recognized as motivated by the problem of unjust or antiquated laws was developed by both Bert Early and William Erickson. They proposed the establishment of a national public agency, governed by the most eminently qualified individuals available, and dedicated to the mission of giving national cohesion and increased public and private support to the inadequate and piecemeal efforts directed towards improving the justice system at all levels. Some of the listed characteristics are common to the American Law Institute. Eventually, the efforts of Early and Erickson led to the establishment of the National Institute of Justice which whose mission is to "advance scientific research, development, and evaluation to enhance the administration of justice and public safety”. Even if the National Institute of Justice plays an important role for the 
improvement of the administration of justice service, it doesn't contribute significantly in reorganizing and clarifying the law.

\section{Conclusion}

For many years, the compelling need to guarantee the right to equal justice shifted scholars' attention to matters related with the application of the law. Consequently, the least dangerous branch of government turned out to be the more examined, meanwhile the most dangerous one was the less studied. Eventually, neither courts nor legislative assemblies alone can be considered completely and exclusively accountable in order to determine what is the law. The communication between judges and legislators Justice Cardozo had in mind mandates, undoubtedly, strong cooperation between them. However, they represent just the poles of a complex and variegated system. In fact, each society is characterized by a peculiar coexistence of several legal processes such as adjudication, contract, customary law, legislation, administrative measure, managerial direction, mediation, and so on, all of which spill over both backward and forward in time. The opportunity to reconcile and organize the different sources of obligation would allow courts to render an equal justice service. Such an opportunity requires the systematization of a proper theory of legislation. As already observed, Wintgens' legisprudence may represent such a theory. As a matter of fact, the outcomes of legislation are not completely predictable, but by the same token a previous examination of its probable effects and a subsequent investigation of its tangible upshots is desirable. As intended by some authors, legisprudence has to include a survey of the impact of legal norms ex ante and ex post to avoid as far as possible undesired and undesirable effects and, also, to rectify those negative consequences not expected nor intended. These tasks can be fulfilled in many different ways. All the models and arrangements already tested or just theorized by scholars have the general purposes of: a) improving the quality of legal norms; b) making the law more comprehensible; and c) facilitating the access to the justice service.

The different models and experiences examined are interesting under three profiles: a) the subjects dedicated to the function of simplifying and clarifying the law; b) the tools used to perform the function; c) the effects produced in the legal systems.

The subjects are sometimes completely integrated in the legislatures (e.g. the United States Office of the Law Revision Counsel, the Italian Committee on Legislation, or the models proposed by Ginsburg, Stevens, Oakes and Nagle); sometimes they work aside as non-departmental bodies but still strongly cooperating with the executives (e.g. the British Law Commission, the original Cour the Cassation, or the models proposed by Friendly and Kramer). In other cases the subjects are totally independent from the government (e.g. the American Law Institute, the Italian Observatories on Justice or the models proposed by Traynor and Early).

The most successful tools, generally adopted, are: a) codifications of the law; b) consolidations of statutes; c) statute law repeal; d) law reform projects; e) restatements of the law and custom protocols; f) analysis of the impact on regulation or quality checklist mechanism.

Any consideration about the effects produced in the legal systems must preliminary distinguish between two different aspects: a) the effectiveness of the tools in simplifying and clarifying the law; b) the tools' impact on the sources of law. With regard to the first aspect, although the essay already reserved much attention to the success of the different models, it is remarkable that the most effective models which demonstrated to have the capability of changing the law durably are characterized by independence, autonomous initiative and self-government.

The second aspect is the one presenting more problems for the doctrine of separated powers. In fact, the idea of a self-governed entity who sets rules or re-states the existing law with a sort of binding authority quakes the Parliament's monopoly of legislation. Restatements, protocols and collective covenants may represent a sort of competitive source of law that stands together Parliament's legislation.

The comparative analysis of the different experiences in Civil law and Common law countries revealed a major tendency to constitute independent bodies by initiative of a law experts elite of lawyers, judges and academics. Generally, these bodies adopt a scientific method in order to produce shared documents which are supposed to represent a valid reference for all the legal operators. Most of the time there is no political influence on the process, contributing to preserve the authoritativeness of the body. Notwithstanding, the documents may be addressed to the parliaments with the purpose to enact law reforms through the legislative process. Out of these cases, the documents are supposed to have mere persuasive value but it is still disputed how they affect the other sources of law when they are widely adopted by courts. 
The main purpose to bring certainty and order out of the wilderness of law has at the base the fundamental right to equal justice. This right entails, on one side, the pursue of jurisprudence uniformity in applying the law and, on the other side, the predictability of a comprehensible law. Justice Cardozo anticipated the need to rule out subjectivity in legislation and adjudication by establishing objective principles that can guide a substantial legal rationality. For these reasons the Ministry of Justice Cardozo envisioned still constitutes an ideal prototype for the research of the certainty and order of the law.

\section{References}

Adams, K. D. (2007a). The American Law Institute: Justice Cardozo’s Ministry of Justice? Southern Illinois University Law Journal, 32, 173-210.

Adams, K. D. (2007b). Blaming the Mirror: The Restatements and the Common Law. Indiana Law Review, 40, 205 (Indianapolis, IN).

Berkowitz, R. (2005). From Science to Technique: Friedrich Carl von Savigny, the BGB, and the Self-Overcoming of Legal Science. The Gift of Science: Leibniz and the Modern Legal Tradition. Cambridge: Harvard University Press.

Berti Arnoaldi Veli, G. (2011). Gli Osservatori sulla Giustizia civile e i protocolli di udienza. Bologna: Ed. Il Mulino.

Bientinesi, F. (2014). Note sul funzionamento del Comitato per la legislazione.

http://archivio.rivistaaic.it/dibattiti/attualita/bientinesi.html

Cadiet, L. (2006). La Legalité procedurale en matiére civile. Paris: Bulletin d'Information de la Cour de cassation.

Calabresi, G. (1983). A Common Law for the Age of Statutes. Cambridge (Mass.): Harvard University Press.

Calabresi, G. (2012). Il mestiere di giudice. Pensieri di un accademico americano. Bologna: Ed. il Mulino.

Calamandrei, P. (1976). La Cassazione civile. Now in Opere Giuridiche. VI. Napoli.

Caponi, R. (2011). L'Attività degli Osservatori sulla Giustizia Civile nel Sistema delle Fonti del Diritto. In Gli Osservatori sulla Giustizia civile e i protocolli di udienza (pp. 57-64). Bologna: Ed. Il Mulino.

Cardozo, B. N. (1921). A Ministry of Justice. Harvard Law Review, 35, 113-126. http://dx.doi.org/10.2307/1328195

Cardozo, B. N. (1924). The Growth of the Law. New Haven, CT: Yale University Press.

Copeland Nagle, J. (1996). Corrections Day. UCLA Law Review, 43, 1267-1268.

Etherton, T. (2007). Law Reform in England and Wales: A Shattered Dream or Triumph of Political Vision? Report of the Bar Law Reform Committee Lecture, London: British and Irish Legal Information Institute.

Feinberg, W. (1976). A National Court of Appeals? 42 Brooklyn Law Review 611.

Flores, I. B. (1995). La técnica jurìdica en la aplicacìon del derecho. Revista de la Facultad de Derecho, México. t. 45, Nos. 201-202.

Friendly, H. J. (1963). The Gap in Lawmaking—Judges Who Can’t and Legislators Who Won’t. Columbia Law Review, 63, 787-807.

Ginsburg, R. B., \& Huber, P. W. (1986). The Intercircuit Committee. Harvard Law Review, 100, 1417-1435.

Ginsburg, R. B. (1987). A Plea for Legislative Review. 60 Southern California Law Review, 995.

Gouvin, E. J. (1994). Truth in Savings and the Failure of Legislative Methodology. 62 University of Cincinnati Law Review $1281,1370$.

Indlekofer, M. (2013). International Arbitration and the Permanent Court of Arbitration. Augsburg: Wolter Kluwer Law \& Business.

Kramer, L. (1991). “The One-Eyed Are Kings”: Improving Congress’s Ability to Regulate the Use of Judicial Resources. Law and Contemporary Problems, 54, 73-97.

Lee, F. P., \& Beaman, M. G. (1927). Legal Status of the New Federal Code. 11 Marquette Law Review, 130-145 (Milwaukee, Wisconsin).

Lynch, M. (1997). The US Code, the Statutes at Large, and Some Peculiarities of Codification. Legal Reference Services Quarterly, 16, 69-84. http://dx.doi.org/10.1300/J113v16n01_04

Magendie, J. C. (2004). Célérité et qualité de la justice. La gestion du temps du procés, Rapport au Garde des Sceaux, ministre de la Justice. Paris: La documentation française.

McKinney, R. J. (2006). Basic Overview on How Federal Laws Are Published, Organized and Cited. FLICC Program on Federal Legislative Research, Law Librarian Society of Washington DC.

Oakes, J. L. (1989). Grace Notes on “Grace under Pressure”. 50 Ohio State Law Journal 701, Columbus, OH.

Paulson, S. L., \& Lischewski Paulson, B. (1998). Normativity and Norms: Critical Perspectives on Kelsenian Themes. Ox- 
ford: Oxford University Press.

Perju, V. (2009). A Comment on "Legisprudence”. Boston University Law Review, 89, 427.

Postema, G. J. (1987). The Normativity of Law. In R. Gavison (Ed.), Issues in Contemporary Legal Philosophy: The Influence of H. L. A. Hart (pp. 81-104). Oxford: Clarendon Press.

Punzi, C. (2010). Il processo civile (Sistema e problematiche). Vol. II, Torino: Giappichelli Ed.

Radaelli, C. M. (2001). L'analisi di impatto della regolazione in prospettiva comparata. Soveria Mannelli: Rubettino Ed.

Stevens, J. P. (1982). Some Thoughts on Judicial Restraint. Judicature, 66, 177-183.

Trantino, E. (2002). Report n. 1/2002. Committee on Legislation of the Italian Parliament. First Presidency, 21 June 200125 April 2002. http://archivio.rivistaaic.it/dibattiti/attualita/rapportocomitatolegis.html

Traynor, R. J. (1968). Statutes Revolving in Common-Law Orbits. Catholic University Law Review, 17, 401.

Tudela, R. (2006). Décret du 28 décembre 2005: Vers une contractualisation de la procédure civile? in Gazz. Pal. Doctr.

United States. Commission on Revision of the Federal Court Appellate System (1975). Structure and Internal Procedures: Recommendations for Change. Washington: The Commission.

van den Berg, A. J. (2013). International Arbitration: The Coming of a New Age. In ICCA Congress Series 17. London: Kluwer Law International.

Vetri, D. (1998). Communicating between the Planets: Law Reform for the Twenty-First Century. Willamette Law Review, 34, 169.

von Savigny, F. K. (1814, 2nd rev. ed. 1828). Vom Beruf unserer Zeit für Gesetzgebung und Rechtswissenschaft (Eng. trans., Frederick Charles von Savigny, (1831) Of the Vocation of Our Age for Legislation and Jurisprudence, Abraham Hayward trans). London: Littlewood.

White, G. E. (1997). The American Law Institute and the Triumph of Modernist Jurisprudence. Law and History Review, 15, 1-47. http://dx.doi.org/10.2307/827704

Wintgens, L. J. (2007). Legitimacy, and Legitimation from the Legisprudential Perspective. In Legislation in Context: Essays in Legisprudence (pp. 3, 4). Farnham: Ashgate Publishing.

Zaccaria, R. (2011). Fuga dalla Legge? Seminari sulla qualità della legislazione. Brescia: Grafo Ed. 
Scientific Research Publishing (SCIRP) is one of the largest Open Access journal publishers. It is currently publishing more than 200 open access, online, peer-reviewed journals covering a wide range of academic disciplines. SCIRP serves the worldwide academic communities and contributes to the progress and application of science with its publication.

Other selected journals from SCIRP are listed as below. Submit your manuscript to us via either submit@scirp.org or Online Submission Portal.
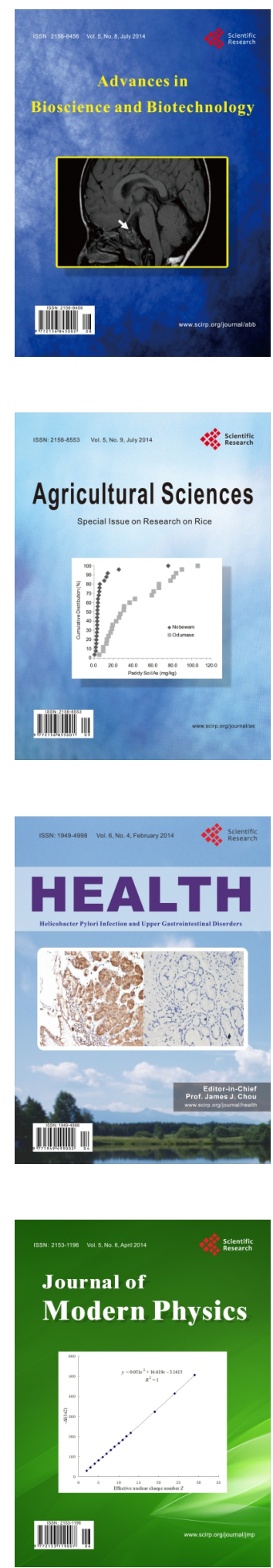
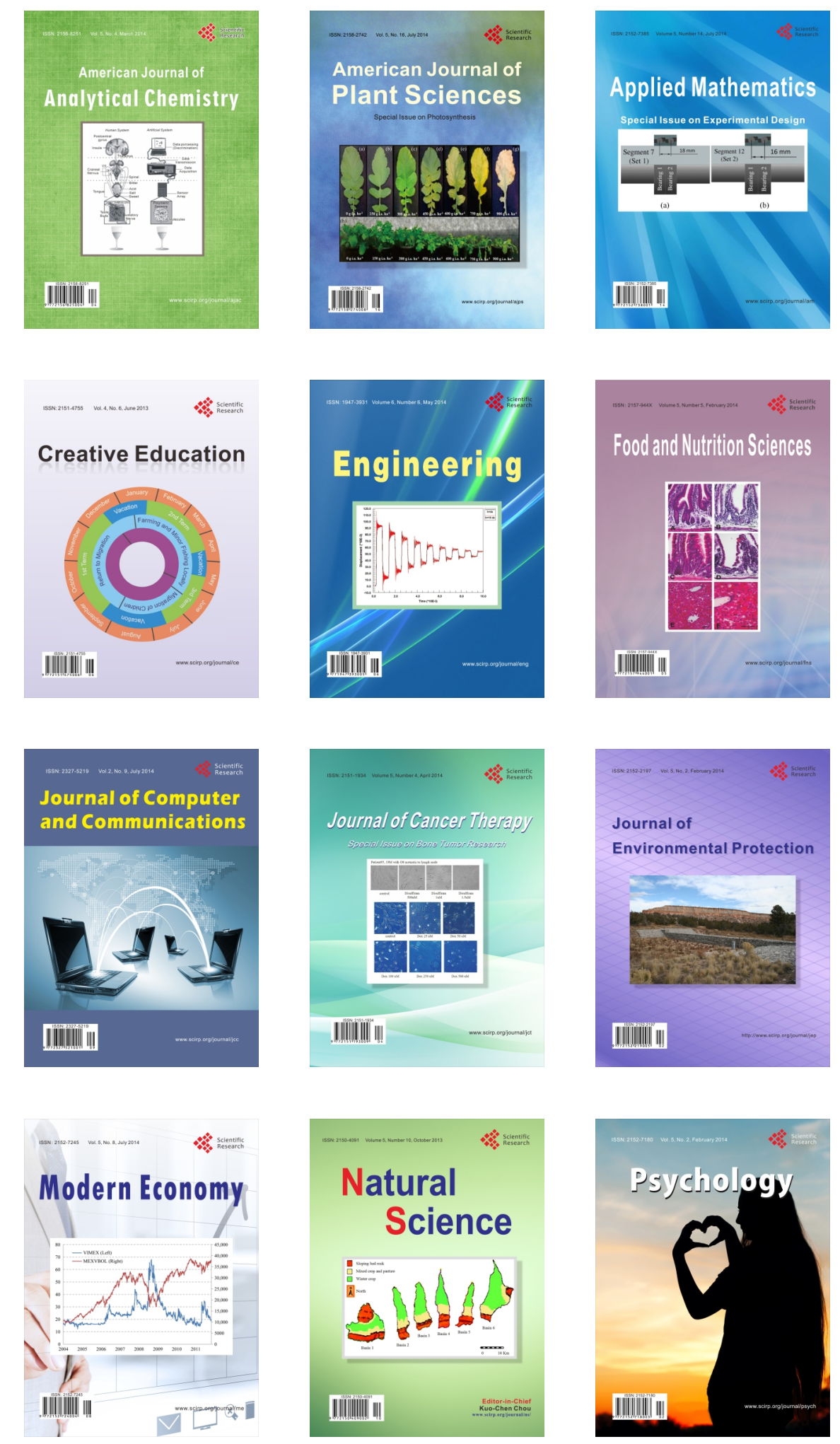